\title{
ISOLATION AND CHARACTERIZATION OF A CHITINASE GENE FROM ENTOMOPATHOGENIC FUNGUS VERTICILLIUM LECANII
}

\author{
Yanping Zhu, Jieru Pan, Junzhi Qiu and Xiong Guan* \\ Key Laboratory of Biopesticide and Chemical Biology, Ministry of Education, Fujian Agriculture and Forestry University, \\ Fuzhou 350002, China
}

Submitted: September 14, 2007; Returned to authors for corrections: November 23, 2007; Approved: January 23, 2008.

\begin{abstract}
Entomopathogenic fungus Verticillium lecanii is a promising whitefly and aphid control agent. Chitinases secreted by this insect pathogen have considerable importance in the biological control of some insect pests. An endochitinase gene Vlchitl from the fungus was cloned and overexpressed in Escherichia coli. The Vlchitl gene not only contains an open reading frame (ORF) which encodes a protein of 423 amino acids (aa), but also is interrupted by three short introns. A homology modelling of Vlchit1 protein showed that the chitinase Vlchit1 has a $(\alpha / \beta)_{8}$ TIM barrel structure. Overexpression test and Enzymatic activity assay indicated that the Vlchit1 is a functional enzyme that can hydrolyze the chitin substrate, so the Vlchitl gene can service as a useful gene source for genetic manipulation leading to strain improvement of entomopathogenic fungi or constructing new transgenic plants with resistance to various fungal and insects pests.
\end{abstract}

Key words: Chitinase, Cloning, Overexpression, Homology modeling, Verticillium lecanii

\section{INTRODUCTION}

Verticillium lecanii is a well-known entomopathogenic fungus which has been commercialized for aphid and whitefly control (11). The host range of the species is wide and includes homopteran insects as well as a range of other arthropod groups. However, the full potential of this fungus as a mycoinsecticide is not yet exploited, mainly because the genetic and molecular basis of its pathogenesis in insects is not fully understood. The penetration of entomopathogenic fungi through the insect cuticle, which comprises mainly chitin fibrils embedded in a protein matrix, is essential for the infection. This key step in the insect infection occurs by a combination of mechanical pressure, via appressorium formation, and enzymatic degradation (2). During the penetration process, entomopathogenic fungi can produce several chitinases, some of which are important cuticle-degrading enzymes and act synergistically with proteases to hydrolyze insect cuticle (16). Chitinases have been implicated as pathogenicity determinants of entomopathogeic fungi (3). However, the roles that chitinases play in the infection process are still unclear (18). Overproduction of Bbchit endochitinase can significantly enhance the virulence of Beauveria bassiana (5), suggesting that chitinase genes are candidates for genetic manipulation leading to virulence improvement of entomopathogenic fungi. Like other entomopathogenic fungi, $V$. lecanii produces chitinases that are able to degrade the cuticle of various insects effectively, and this aspect highlights the biocontrol potential of this fungus to insect pests $(7,8)$. Although chitinases of $V$. lecanii have considerable importance in the biological control of some insect pests, only two chitinase genes from this fungus have been reported till now. In order to better understand the role of chitinases in $V$. lecanii entomopathogenicity, we isolated and characterized the Vlchitl gene for further development of more efficient strains for the control of specific insect pests through genetic manipulation.

\section{MATERIALS AND METHODS}

\section{Fungal and bacterial strains}

$V$. lecanii strain Aa was originally isolated from a citrus whitefly Dialeurodes citri from a citrus-growing orchard in

*Corresponding Author. Mailing address: Key Laboratory of Biopesticide and Chemical Biology, Ministry of Education, Fujian Agriculture and Forestry University, Fuzhou 350002, China. E-mail: guanxfafu@126.com or gxfafu@fjau.edu.cn 
Fujian, China, in 2000. A single-spore isolate of Aa was stored in $20 \%$ glycerol at $-80^{\circ} \mathrm{C}$. Cultures were grown on potato dextrose agar (PDA) at $25^{\circ} \mathrm{C}$ with a daily cycle consisting of $15 \mathrm{~h}$ of light and 9 h of darkness. E. coli JM109 and TB1 were employed for DNA manipulation.

\section{DNA and RNA preparation}

V. lecanii mycelia were inoculated on PDA plate with cellophane. Cultures grown for 3 days were used for DNA extraction or transferred to induction medium $(\mathrm{KCl} 0.05 \%(\mathrm{w} / \mathrm{v})$, $\mathrm{MgSO}_{4} 0.05 \%$ (w/v), $\mathrm{KH}_{2} \mathrm{PO}_{4} 0.05 \%$ (w/v), $\mathrm{Na}_{2} \mathrm{HPO}_{4} 0.065 \%$ (w/ $\mathrm{v})$, Chitin $1 \%(\mathrm{w} / \mathrm{v}))$ for chitinase induction. After $12 \mathrm{~h}$ induction, mycelia were harvested by filtration and washed with sterile distilled water three times, and then subjected to RNA extraction. DNA and RNA from $V$. lecanii were prepared as described by Reader and Broda (13) and Chomczynski and Sacchi (4), respectively. First strand cDNA for PCR amplification was synthesized by using AMV First Strand cDNA Synthesis Kit (BBI) in term of manufacturer's manual.

\section{Gene cloning and sequencing}

Five different fungal chitinase sequences (B. bassiana, accession number $\underline{\mathbf{A Y 1 4 5 4 4 0}}$, Metarhizium anisopliae, accession number $\underline{\mathbf{A F 0 2 7 4 9 8}}$, Nomuraea rileyi, accession number AY264288, Metarhizium flavoviride, accession number AJ243014, Verticillium fungicola, accession number AY292527) from different genera of Hypocreales were selected and aligned using DNAStar to identify conserved regions used to design the degenerate primers chitU $\left(5^{\prime}\right.$-GCCGTCTAC TTCACCAAYTGG- 3') and chitD (5'-CCAGCATAGTCGTA GGCCAT-3'). The amplification conditions for the partial sequence of Vlchit 1 were: $5 \mathrm{~min}$ at $95^{\circ} \mathrm{C}$ denaturation, followed by 30 cycles of $94^{\circ} \mathrm{C}$ for $1 \mathrm{~min}, 57^{\circ} \mathrm{C}$ for $1 \mathrm{~min}$ and $72^{\circ} \mathrm{C}$ for $2 \mathrm{~min}$, and a final extension at $72^{\circ} \mathrm{C}$ for $10 \mathrm{~min}$.

According to the partial sequence of endochitinase gene Vlchit1 which was amplified with degenerate primers, gene specific primers GSP1 (5'-GCGGCAATAGAAAGCAGGA AATGG-3') and GSP2 (5'-GGCGATACCTATGCGGACTA CGAG-3') were designed for 5' RACE and 3' RACE, respectively. 5' RACE and 3' RACE were conducted by using BD SMART ${ }^{\text {TM }}$ RACE cDNAAmplification Kit (Clontech) as recommended by manufacturer.

According to the hypothetical open reading frame (ORF) sequence deduced by analyzing contig assembled with 5 ' and 3' RACE sequence, primers ORFup (5'-CCGGAATT CATGTTGAGCCTACTCAAAAAA-3') which contained an EcoRI site before the ATG codon, and ORFdown (5'-CCCA AGCTTCTATTTCATGCCATTCTTGAT-3') which had a HindIII site after the stop codon were designed for ORF amplification. The total DNA and first strand cDNA were used as template respectively, and the amplification parameters were as follows: 5 min of denaturation at $95^{\circ} \mathrm{C}$, followed by 30 cycles of denaturation for $1 \mathrm{~min}$ at $94^{\circ} \mathrm{C}$, annea7ling for $1 \mathrm{~min}$ at $50^{\circ} \mathrm{C}$, and extension for $2 \mathrm{~min}$ at $72^{\circ} \mathrm{C}$. An extra extension step consisting of $10 \mathrm{~min}$ at $72^{\circ} \mathrm{C}$ was added after completion of the 30 cycles.

All sequences were cloned to pMD18-t Vector (Takara), transformed into E. coli JM109 and sequenced by Takara Bio Company (Dalian, China).

\section{Homology modelling}

The deduced amino acid sequence from chitinase gene Vlchit 1 was used in homology modelling. Homology modelling was done using the program Swiss-model (15) and protein structures and models were viewed by software DeepViewSwiss-PdbViewer (http://swissmodel.expasy.org//SWISSMODEL.html ).

\section{Production of recombinant overexpression vector}

ORF of Vlchit1 was cloned into the pMAL-c $2 \mathrm{X}$ overexpression vector (NEB) and fused to the malE gene that encodes maltose-binding protein (MBP) to construct recombinant overexpression vectors. The vector $\mathrm{pMAL}-\mathrm{c} 2 \mathrm{X}$ was double digested with the EcoRI and HindIII. Amplified ORF of Vlchit 1 were purified from the DNA gel using NucleoTrap ${ }^{\circledR}$ Gel Extract Kit (Clontech) and were digested with EcoRI and HindIII. Ligation of the insert to the overexpression vector pMAL-c2X vector was performed following the protocol in the NEB technical manual. Transformations of TB1 cells were performed following the protocol in Sambrook et al. (14). In-frame insertion of Vlchit1 with the sequence of MBP in the recombinant clone was selected and verified by digestion analyses with restriction enzyme EcoRI and HindIII as well as DNA sequencing.

\section{Overexpression and purification of MBP fusion proteins}

Selected clones of Vlchit 1 were grown at $37^{\circ} \mathrm{C}$ in $0.5 \mathrm{~L}$ rich broth + glucose \& amp (per liter: $10 \mathrm{~g}$ tryptone, $5 \mathrm{~g}$ yeast extract, $5 \mathrm{~g} \mathrm{NaCl}, 2 \mathrm{~g}$ glucose autoclave; add sterile ampicillin to $100 \mu \mathrm{g} /$ $\mathrm{ml}$ ) cultures on a rotary shaker. Glucose was added to the growth medium to repress the maltose genes on the chromosome of the $E$. coli host, one of which codes for amylase that can degrade the amylose on the affinity resin that is used for purification. The cells were induced for $4 \mathrm{~h}$ with $0.3 \mathrm{mM}$ IPTG (isopropylthiogalactoside) at $37^{\circ} \mathrm{C}$ when the culture OD600 was between 0.4 and 0.6. Both induced and uninduced cells were harvested and resuspended in column buffer $(20 \mathrm{mM}$ Tris- $\mathrm{HCl}$ (pH 7.4), $200 \mathrm{mM} \mathrm{NaCl}$, and $1 \mathrm{mM}$ EDTA with or without $1 \mathrm{mM}$ DTT) and sonicated. Equal amounts of protein samples of ruptured induced and uninduced cells were loaded on a $10 \%$ SDS-polyacrylamide gel and subjected to electrophoresis to verify the overexpression of the recombinant protein.

The fusion protein was purified by one-step affinity chromatography using amylose resin (NEB). Amylose resin (1 $\mathrm{ml}$ of amylose resin binds $3 \mathrm{mg}$ of the recombinant protein) was mixed with the crude ruptured cell extract on a shaker at $4{ }^{\circ} \mathrm{C}$ for 
$2 \mathrm{~h}$ and poured into a $2.5-\mathrm{cm} \times 10-\mathrm{cm}$ column to perform batch purification. The column was washed with $1.5 \mathrm{~L}$ of column buffer to remove other proteins. At the final step, fusion proteins were eluted from the column by column buffer containing $10 \mathrm{mM}$ maltose.

The protein concentration was determined by using Bradford Method.

\section{Gel electrophoresis}

Protein analysis was performed on $10 \%$ sodium dodecyl sulfate-polyacrylamide gel electrophoresis (SDS-PAGE). Protein samples were reduced by boiling for 5-10 min in loading buffer containing $5 \% \beta$-mercaptoethanol and then centrifuged at $10,000 \mathrm{~g}$ for $5 \mathrm{~min}$ prior to loading the gel. Vertical slab gels, containing $10 \%(\mathrm{w} / \mathrm{v})$ resolving gel and $5 \%$ stacking gel concentrations of acrylamide, were run at a constant current of $15 \mathrm{~mA}$ for $6 \mathrm{~h}$. The proteins on PAGE gels were fixed in $45 \%$ methanol and $10 \%$ acetic acid in distilled water, stained in $0.25 \%$ Coomassie brilliant blue R-250 dissolved in 10\% acetic acid and $50 \%$ methanol in water. The gels were destained for $3 \mathrm{~h}$ in $5 \%$ methanol and $7 \%$ acetic acid in distilled water.

\section{Enzymatic activity assay}

Chitinase activity was determined by measuring the reducing end group $\mathrm{N}$-acetylglucosamine produced from colloidal chitin. Reaction mixture consisting $0.5 \mathrm{ml}$ enzyme solution, and $0.5 \mathrm{ml}$ of $1 \%(\mathrm{w} / \mathrm{v})$ colloidal chitin $(\mathrm{pH} 7.0)$ was cubated at $40^{\circ} \mathrm{C}$ for $2 \mathrm{~h}$. Termination of the reaction was done by adding $1 \mathrm{ml}$ dinitrosalicylic acid reagent and heating in boiling water for $5 \mathrm{~min}$. The reaction was then cooled to room temperature, and centrifuged at $10,000 \mathrm{~g}$ for $10 \mathrm{~min}$. The supernatant was subjected to spectrophotometric measurement at $530 \mathrm{~nm}$. One unit of chitinase activity was defined as the amount of enzyme that released sugars equivalent to $1 \mu \mathrm{mol}$ of $\mathrm{N}$-acetylglucosamine per min at $40^{\circ} \mathrm{C}$.

\section{RESULTS AND DISCUSSION}

\section{Cloning and sequence analysis of the endochitinase gene Vlchit1}

With the first strand cDNA and degenerate primers, a partial sequence of $688 \mathrm{bp}$ was obtained by PCR amplification. Sequence analysis by NCBI BLAST (http://www.ncbi.nlm. nih.gov/blast/) showed that the sequence has high levels of identity with fungal chitinases. Based on the initial sequence gene specific primers GSP1 and GSP2 were designed and a 1567 bp sequence was acquried by 5' and 3' RACE reactions. Sequence analysis indicated that the full length of the chitinase cDNA contained a 95-bp untranslated sequence at the 5' end, a 1272-bp ORF encoding 423-amino-acid endochitinase precursor, and an untranslated region of $200 \mathrm{bp}$ at the 3 ' end terminating with a poly(A) tail. The sequence of the ORF deduced from the
3' and 5'RACE reactions was confirmed by conducting RT-PCR with primers ORFup and ORFdown. The resulting $1272 \mathrm{bp}$ band was sequenced and shown to be identical to that obtained by RACE-PCR amplification. However, amplification of the genomic DNA with the same primers produced a 1,432-bp band. The overlapping amplified regions above resolved the Vlchit1 gene (GenBank accession number DQ412944). The entire sequence is 1,699-bp long with 4 exons and 3 introns (Fig. 1). These introns contain the conserved 5' GT and 3' AG ends.

Analysis of the deduced Vlchitl protein sequence using the program SignalP 3.0 Server (1) (http://www.cbs.dtu.dk/services/ SignalP ) predicted a 22 aa signal sequence containing a hydrophobic structure and a signal sequence cleavage site located between aa 22 and 23. Analysis using ProtParam Tool (6) (http://www.expasy.org/tools/protparam.html) revealed that the 401 aa mature chitinase (without signal peptide) has a molecular mass of $43.7 \mathrm{kDa}$, an aliphatic index of 69.18 , a grand average of hydropathicity (GRAVY) of -0.371 and is considered to be a stable protein with an instability index of 26.89. Furthermore, the chitinase is an acidic protein with a theoretical $\mathrm{pI}$ of 5.55. Two highly conserved regions (SXGG and DXXDXDXE) of the active domain of the family 18 glycosyl hydrolases were identified in the deduced amino acid sequence of Vlchit1 (Fig. 1), indicating that $V l c h i t 1$ was a member of glycosyl hydrolase family 18 . The potential substrate binding site (VMLSIGG) where X of XXXSXGG represents hydrophobic domain was located at aa site 124 and the catalytic active site (FDGIDIDWE) was located at aa 163 site where glutamic acid (Glu171) is the critical residue involved as the proton donor in the catalytic doubledisplacement mechanism during hydrolysis $(12,18)$.

A BLAST search showed that the deduced amino acid sequence of Vlchit1 has a high homology to chitinases from other entomopathogenic fungi. The Vlchit1 showed $69 \%, 70 \%$, $72 \%, 74 \%, 74 \%$ and $92 \%$ identity to chitinases from $M$. anisopliae (accession number AAY32603), M. flavoviride (accession number CAB44709), B. bassiana (accession number AAN41260), $N$. rileyi (accession number $\mathbf{A A P 0 4 6 1 6}$ ), Paecilomyces fumosoroseus (accession number $\underline{\mathbf{A A X 1 9 1 4 6}}$ ) and Isaria farinose (accession number $\underline{\mathbf{A B D 6 4 6 0 6}}$ ), respectively. Compared with other chitinases from V. lecanii, it could be found that the amino acid sequence encoded by Vlchit 1 showed $91.7 \%$ and $48.1 \%$ sequence homology to CHI2 (accession number AAV98691) and CHI1 (accession number $\underline{\mathbf{A A X 5 6 9 6 0}}$ ) (10) respectively. Although Vlchit1 displayed significant homology to CHI2, there was obvious difference between their $\mathrm{pI}$ values. The deduced $\mathrm{pI}$ value of Vlchit1 is 5.55, indicating Vlchit1 is an acidic chitinase, whereas CHI2 was predicted to have a $\mathrm{pI}$ value of 7.61 , which suggests CHI2 belong to the basic chitinase subgroup (10).

\section{Modelling of Vlchit1 protein}

The deduced amino acid sequence of the Vlchit 1 protein was submitted to the automated comparative protein modeling 
80

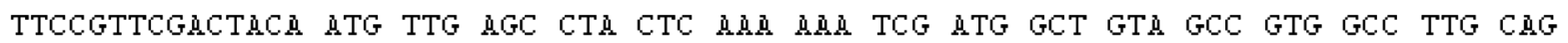

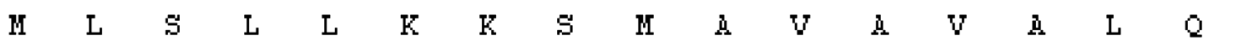

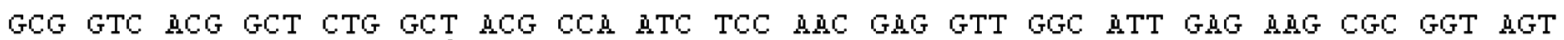
$\begin{array}{llllllllllllllllllllll}\mathbf{A} & \mathrm{V} & \mathrm{T} & \mathrm{A} & \mathrm{L} & \mathbf{A} & \downarrow & \mathrm{T} & \mathrm{P} & \mathrm{I} & \mathrm{S} & \mathrm{N} & \mathrm{E} & \mathrm{V} & \mathrm{G} & \mathrm{I} & \mathrm{E} & \mathrm{K} & \mathrm{R} & \mathrm{G} & \mathrm{S}\end{array}$ GGC TTC GCA AAT GCT GTT TAC TTC ACC AAC TG GTTTGTTCGACTTTTÄTTCTTCAGCTTTCTTCCACA $\begin{array}{lllllllllllllll}G & F & \mathbf{A} & \mathrm{N} & \mathrm{A} & \mathrm{V} & \mathrm{Y} & \mathrm{F} & \mathrm{T} & \mathrm{N} & \mathrm{W}\end{array}$ CTTGATTAHCAARGGGCAG G GGC ATC TAC GGC CGT AAC TTC CAG CCC GCA GAC CTT CCA GCT TCG $\begin{array}{llllllllllllllll}G & I & Y & G & R & N & F & Q & P & \text { A } & D & L & P & \text { A } & S\end{array}$ GAG ATC ACC CAT GTG CTC TAT TCT TTC ATG ÄC ATC CGC TCA GAT GGC ACC AT GTAAGTCAT $\begin{array}{lllllllllllllllllll}\mathrm{E} & \mathrm{I} & \mathrm{T} & \mathrm{H} & \mathrm{V} & \mathrm{L} & \mathrm{Y} & \mathrm{S} & \mathrm{F} & \mathrm{M} & \mathrm{N} & \mathrm{I} & \mathrm{R} & \mathrm{S} & \mathrm{D} & \mathrm{G} & \mathrm{T} & \mathrm{I}\end{array}$ CCTTCATATAGGCTGAATACGAACTGATCAAGGCGÄÄG C TTT TCT GGC GAT ACC TAT GCG GAC TAC $\begin{array}{llllllllll}F & S & G & D & T & Y & \text { A } & D & Y\end{array}$ GHG AHG CAC TAC CCT GGT GHC T GTHAGHAGCCDCAHTCTTTTGGTATHAGTGATCACTHACATGCTTTH $\begin{array}{llllllllllllll}E & \mathrm{~K} & \mathrm{H} & \mathrm{Y} & \mathrm{P} & \mathrm{G} & \mathrm{D} & \mathrm{S}\end{array}$

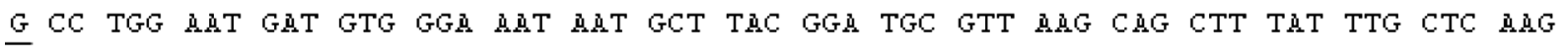

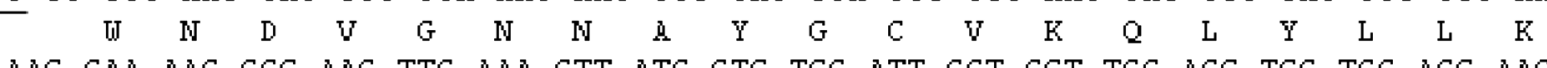

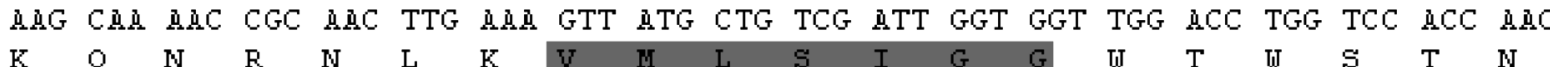
TTT CCC GCT GCT GCC AGC TCT GCT ACC AGC CGA AAG ACT TTC GCT CAA TCT GCC GTT GGT

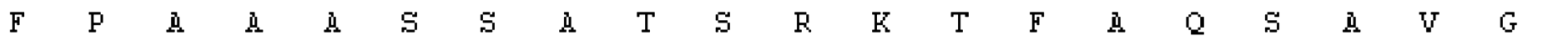

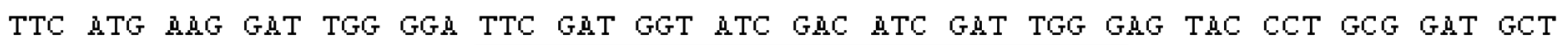
$\begin{array}{llllllllllllllllllll}\mathrm{F} & \mathrm{M} & \mathrm{K} & \mathrm{D} & \mathrm{J} & \mathrm{G} & \mathrm{F} & \mathrm{D} & \mathrm{G} & \mathrm{I} & \mathrm{D} & \mathrm{I} & \mathrm{D} & \mathrm{W} & \mathrm{E} & \mathrm{Y} & \mathrm{P} & \text { म } & \mathrm{D} & \text { A }\end{array}$

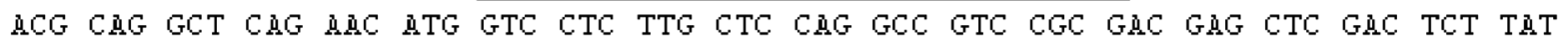
$\begin{array}{lllllllllllllllllllll}T & Q & \mathbf{A} & Q & N & M & V & L & L & L & Q & \text { A } & V & R & D & E & L & D & S & Y\end{array}$ GCC TCG CAG TAT GCC ẢẢ GGC CAC CAT TTC CTG CTT TCT ÄTT GCC GCC CCC GCT GGA CCT $\begin{array}{llllllllllllllllllll}\text { A } & \mathrm{S} & \mathrm{Q} & \mathrm{Y} & \mathbf{A} & \mathrm{K} & \mathrm{G} & \mathrm{H} & \mathrm{H} & \mathrm{F} & \mathrm{L} & \mathrm{L} & \mathrm{S} & \mathrm{I} & \text { A } & \text { A } & \mathrm{P} & \text { मे } & \mathrm{G} & \mathrm{P}\end{array}$

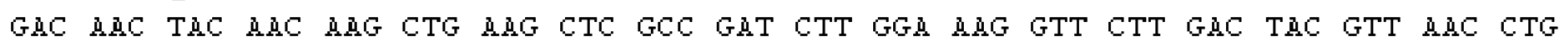
$\begin{array}{llllllllllllllllllllll}D & N & Y & N & K & L & K & L & A & D & L & G & K & V & L & D & Y & V & N & L\end{array}$ ATG GCC TAC GAC TTT GCC GGC TCG TGG AGT ÄL TTC ACC GGC CAC GAC GCC

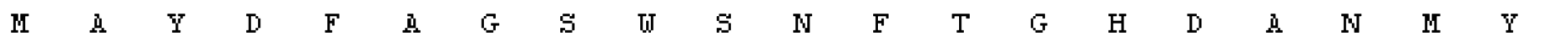
GCC AGC AAG GAC AAT GCT AAT GCA ACT CCT TTT AAT ACA AAT GAT GCT GTT CAG GCG TAC $\begin{array}{llllllllllllllllllll}\mathbf{A} & \mathrm{S} & \mathrm{K} & \mathrm{D} & \mathrm{N} & \mathbf{A} & \mathrm{N} & \mathbf{A} & \mathrm{T} & \mathrm{P} & \mathrm{F} & \mathrm{N} & \mathrm{T} & \mathrm{N} & \mathrm{D} & \mathbf{A} & \mathrm{V} & \mathrm{Q} & \mathbf{A} & \mathrm{Y}\end{array}$ ATC AДA GGA GGT GTC CCT GCC AGC AूA ATT GTC CTG GGT ATG CCC ATC TAC GGT CGG TCT $\begin{array}{lllllllllllllllllllll}I & K & G & G & V & P & d & S & K & I & V & L & G & M & P & I & Y & G & R & S\end{array}$ TTC GAG AHG ACT GAG GGA ATT GGC AूG CCA TAC AMC GGT ATC GGC TCT GGC AGC TGG GAG $\begin{array}{lllllllllllllllllllll}\mathrm{F} & \mathrm{E} & \mathrm{K} & \mathrm{T} & \mathrm{E} & \mathrm{G} & \mathrm{I} & \mathrm{G} & \mathrm{K} & \mathrm{P} & \mathrm{Y} & \mathrm{N} & \mathrm{G} & \mathrm{I} & \mathrm{G} & \mathrm{S} & \mathrm{G} & \mathrm{S} & \mathrm{W} & \mathrm{E}\end{array}$

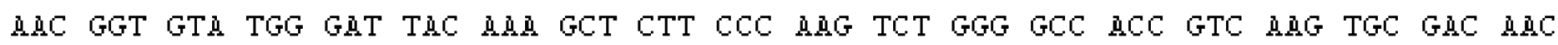

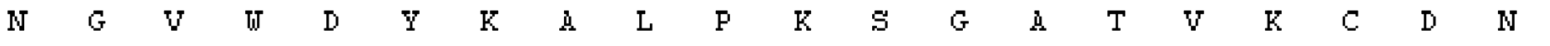

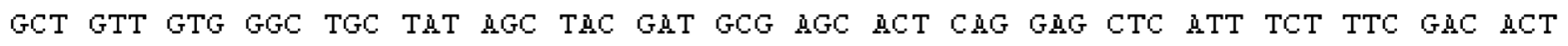

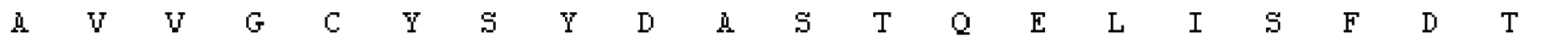
CCA GCT GTT ATC AAC ACC AAG GTT AGC TGG CTT AMG GGC CHG GGA CTC GGT GGA AGC ATG

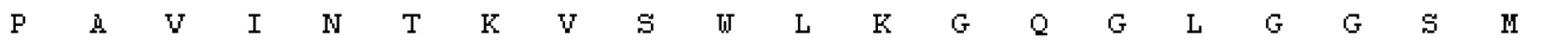

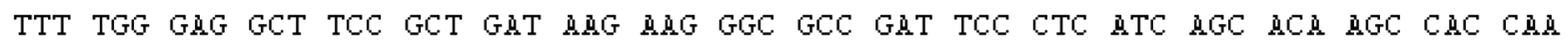

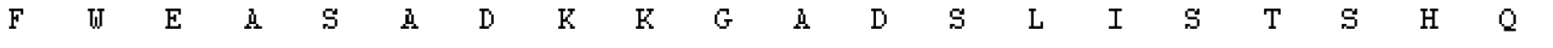
GGT CTT GGT AGC CTG GAC AGC GCT CAG AAC TGC CTT GAC TAC CCC AAC TCA IAG TAT GAC

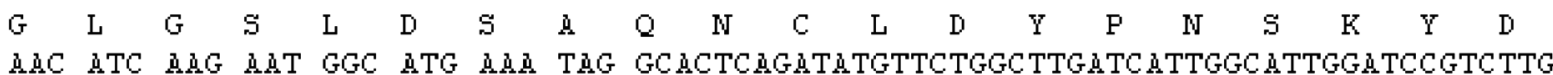
N $\quad \mathrm{I} \quad \mathrm{K} \quad \mathrm{N} \quad \mathrm{G} \quad \mathrm{M} \quad \mathrm{K}$ * CCCTGTACATATTACGCTGCACTGCCCACACTCAAGCTTGACÄGACTTTCCATACTTTTATTGTACATATTATAGATG TCACGATCATGTACATAGTCÄTGACTTCACTTTCTTTTTTTCGG

143 16 203 36 272 47 338 62 400 80 470 89 543 97 603 116 663 136 723 156 783 176 843 196 903 216 963 236 1023 256 1086 276 1143 296 1203 316 1263 336 1323 356 1383 376 1443 396 1503 416 1574 423 1653 1699

Figure 1. Nucleotide sequence of endochitinase gene Vlchit1. The deduced amino acid sequence is shown in one-letter code under the ORF. The three introns are underlined. The putative substrate binding site and catalytic domain of the fungal chitinase are shaded. The cleavage site of the signal peptide is indicated by an arrow. 
server (http://swissmodel.expasy.org//SWISS-MODEL.html). Five chitinases (1w9v, 1w9p, 1w9u, 2a3b,$\underline{\mathbf{2 a 3 a}}$, at the Protein Data Bank http://www.rcsb.org/pdb/) with the highest identity to Vlchit1 in amino acid sequence were chosen as modeling templates. The Homology model of the Vlchit1 protein and its active domain are showed in Fig. 2. Homology modeling showed that the Vlchit1 chitinases contain the $(\alpha / \beta)_{8}$ TIM barrel structure like other members of the class 18 hydrolase family. Several kinds of glycosylhydrolases have a similar $(\alpha / \beta)_{8}$ TIM barrel structure, which may indicates that this structure may be

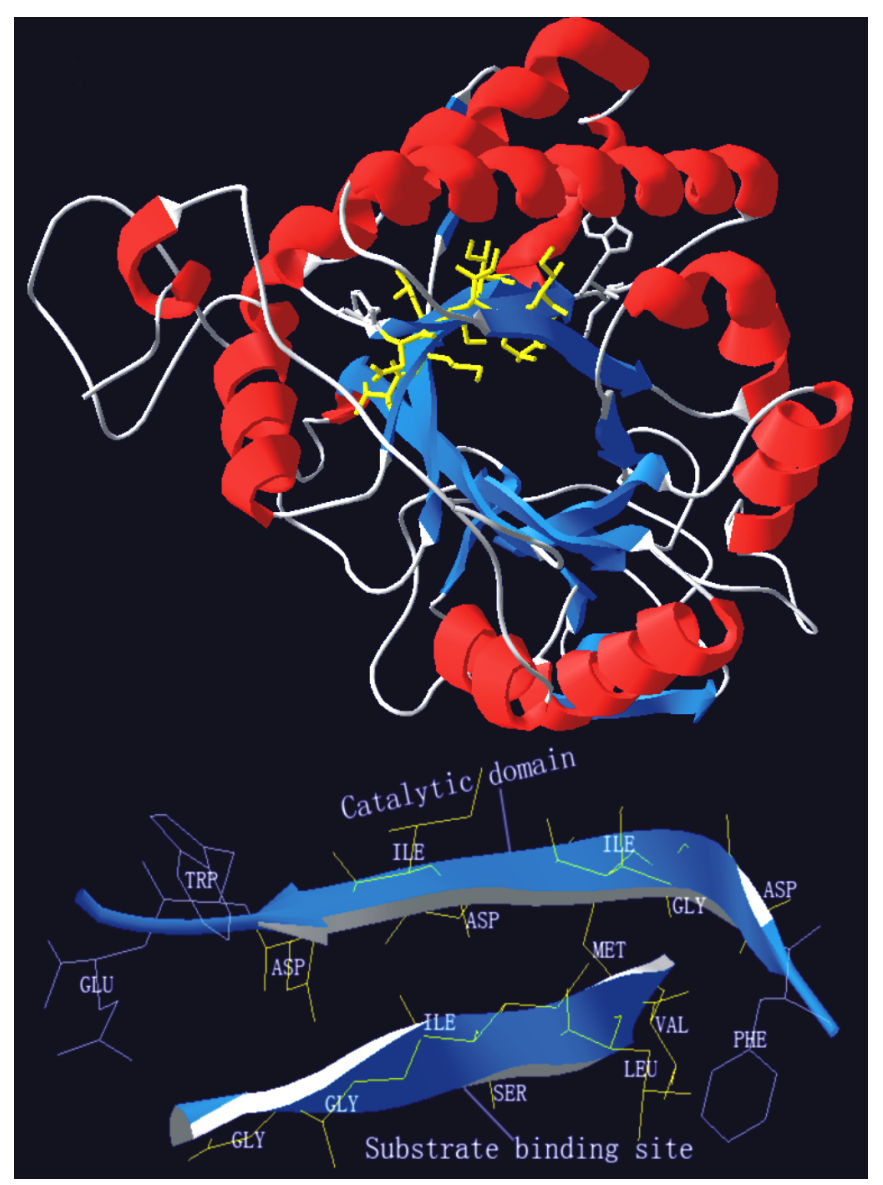

Figure 2. Homology modelling of Vlchit1 protein and its active domain. The SWISS-MODEL program was used to generate the models. (a) Homology model of the Vlchit1 protein, five proteins $(\underline{\mathbf{1 w 9 v}}, \underline{\mathbf{1 w 9 p}}, \underline{\mathbf{1 w 9 u}}, \underline{\mathbf{2 a 3 b}}, \underline{\mathbf{2 a 3 a}}$, at the Protein Data Bank http://www.rcsb.org/pdb/) with the highest identity in amino acid sequence were chosen as modeling templates. The side chains of putative active domains are shown. (b) Homology model of the putative active domain. The deduced catalytic domain (PHE-ASP-GLY-ILE-ASP-ILE-ASP-TRP-GLU) and substrate binding site (VAL-MET-LEU-SER-ILE-GLY-GLY) are indicated. important for the hydrolysis of polymeric substrates. Proteins belonging to the class 18 family of chitinases have two conserved regions, as seen in Fig. 1 corresponding to the putative substrate binding site and catalytic domain of Vlchitl. The two signature sequences which lie along barrel strands 3 and 4 of the class 18 chitinases help form the active site cleft on the carboxyl end of the $\beta$-barrel and appear to be important both for stability of the fold and for catalytic activity $(9,17)$.

\section{Overexpression and purification of MBP fusion proteins}

Preliminary experiment found that $E$. coli cells harboring the recombinant would produce the maximum quantity of MBPVlchit 1 fusion protein when induced with $0.3 \mathrm{mM}$ IPTG for $4 \mathrm{~h}$ at $37^{\circ} \mathrm{C}$. The recombinant protein MBP-Vlchitl was obtained through affinity chromatography purification using amylose resin. The MBP-Vlchit1, total proteins from induced and uninduced cells containing recombinant pMAL-c2X-Vlchit1, total proteins from induced $E$. coli cells harboring vector pMAL-c2X and total proteins from induced $E$. coli cells were loaded on a $10 \%$ SDS-polyacrylamide gel and subjected to electrophoresis (Fig. 3). Recombinant protein MBP-Vlchit1 is about $88.4 \mathrm{kDa}$.

\section{Enzymatic activity assay}

Purified recombinant protein MBP-Vlchit1, total proteins from induced cells containing recombinant pMAL-c2X-Vlchit1,

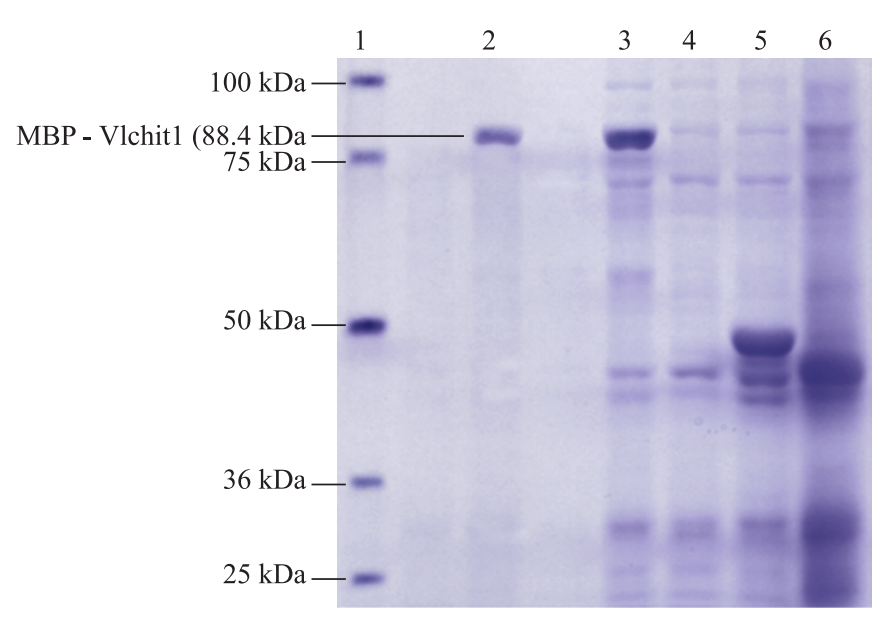

Figure 3. A $10 \%$ SDS-polyacrylamide gel showing overexpression of recombinant pMAL-c2X-Vlchit1. Lane 1 represents molecular mass markers. Lanes 2 represents purified recombinant protein MBP-Vlchit1. Lanes 3 and 4 represent total proteins from induced and uninduced $E$. coli TB1cells containing recombinant pMAL-c2X-Vlchit1, respectively. Lanes 5 represents total proteins from induced $E$. coli TB1 cells harboring vector pMAL-c2X. Lanes 6 represents total proteins from induced $E$. coli TB1 cells. 
Table 1. The concentrations and chitinase activitys of proteins subjected to chitinase activity assay.

\begin{tabular}{lccc}
\hline \multicolumn{1}{c}{ Sample name } & $\begin{array}{c}\text { Concentration } \\
(\mathrm{mg} / \mathrm{ml})\end{array}$ & $\begin{array}{c}\text { Chitinase activity } \\
(\mathrm{mU} / \mathrm{ml})\end{array}$ & $\begin{array}{c}\text { Specific activity } \\
(\mathrm{mU} / \mathrm{mg})\end{array}$ \\
\hline Total proteins from induced E. coli TB1 cells containing & & & \\
recombinant pMAL-c2X-Vlchit1 & $0.89 \pm 0.02$ & $53.1 \pm 1.09$ & $59.66 \pm 1.23$ \\
Total proteins from induced $E$. coli TB1 cells harboring & & & \\
vector pMAL-c2X & $1.27 \pm 0.09$ & 0 & 0 \\
Total proteins from induced $E$. coli TB1 cells & $0.94 \pm 0.01$ & 0 & 0 \\
Purified recombinant protein MBP-Vlchit1 & $0.39 \pm 0.02$ & $47.39 \pm 1.11$ & $121.52 \pm 2.84$ \\
\hline
\end{tabular}

The concentrations, chitinase activities and specific activities are means \pm standard deviations of the means based on three replicates.

total proteins from induced $E$. coli cells harboring vector pMAL-c2X and total proteins from induced E. coli cells were subjected to chitinase activity assay. Chitinase activity was detected in the purified recombinant protein MBP-Vlchit1 and total proteins of cells containing recombinant pMAL-c2XVlchit1, but not in total proteins from induced E. coli cells harboring vector pMAL-c2X and total proteins from induced E. coli cells (Table 1). The result indicates that the Vlchit1 protein has obvious chitinase activity.

We have cloned the chitinase gene Vlchit1 from the entomopathogenic fungi $V$. lecanii. The successful overexpression of the Vlchitl gene in prokaryotic expression system indicated that Vlchit 1 is a functional enzyme that can hydrolyze the chitin substrate. So the Vlchit1 gene can service as a useful gene source for genetic manipulation leading to strain improvement of entomopathogenic fungi or constructing new transgenic plants with resistance to various fungal and insects pests. Further study on constructing recombinant $V$. lecanii strains which are able to overproduce Vlchit1 chitinase is currently under way in this laboratory.

\section{ACKNOWLEDGEMENTS}

This research was supported by grants from Chinese National Natural Science Foundation (30500005), Fujian Provincial Science Foundation for Innovative Young Scholarship (2005J016), Fujian Provincial Educational Programs for Science and Technology Development (JA05239) and Anhui Provincial Key Lab for Microbial Control (2004A04).

\section{RESUMO}

\section{Isolamento e caracterização de um gene de quitinase do fungo entomopatogênico Verticillium lecanii}

O fungo entomopatogênico Verticillium lecanii é um agente promissor no controle da mosca-branca e do pulgão. As quitinases secretadas por esse patógeno de insetos têm uma grande importância no controle biológico de doenças causadas por insetos. Um gene de endoquitinase Vlchitl desse fungo foi clonado e expresso em Escherichia coli. O gene Vlchit contém não apenas um ORF que codifica uma proteína de 423 aminoácidos, mas também é interrompido por três pequenos introns. A modelagem de homologia da proteína Vlchit1 indicou que a quitinase Vlchit1 tem uma estrutura (a/b)8 TIM barrel. Testes de expressão e de atividade enzimática indicaram que Vlchit 1 é uma enzima funcional que hidroliza quitina, portanto o gene Vlchit pode ser um gene útil para manipulação genética para melhoramento de cepas de fungos entomopatogênicos ou para a construção de novas plantas transgênicas com resistência a várias doenças causadas por fungos e insetos.

Palavras-chave: quitinase, clonagem, modelagem por homologia, Verticillium lecanii

\section{REFERENCES}

1. Bendtsen, J.D.; Nielsen, H.; Heijne, G. von; Brunak, S. (2004). Improved prediction of signal peptides: SignalP 3.0. J. Mol. Biol. 340, 783-795

2. Bogo, M.R.; Rota, C.A.; Pinto, J.H.; Ocampos, M.; Correa, C.T.; Vainstein, M.H.; Schrank, A. (1998). A chitinase encoding gene (chit1 gene) from the entomopathogen Metarhizium anisopliae: isolation and characterization of genomic and full-length cDNA. Curr. Microbiol. 37, 221-225.

3. Charnley, A.K.; St. Leger, R.J. (1991). The role of cuticle-degrading enzymes in fungal pathogenesis in insects. In: Cole, E.T., Hoch, H.C. (eds). Fungal spore disease initiation in plants and animals. Plenum Press, NewYork, London, p. 267-287.

4. Chomczynski, P.; Sacchi, N. (1981). Single-step method of RNA isolation by acid guanidinium thiocyanate-phenol-chlorform extraction. Anal. Biochem. 162, 156-159.

5. Fang, W.G.; Leng, B.; Xiao, Y.H.; Y. Pei et al. (2005). Cloning of Beauveria bassiana chitinase gene Bbchit1 and its application to improve fungal strain virulence. Appl. Environ. Microb. 71, 363-370.

6. Gasteiger, E.; Hoogland, C.; Gattiker, A.; Duvaud, S.; Wilkins, M.R.; Appel, R.D.; Bairoch, A. (2005). Protein identification and analysis tools on the ExPASy Server. In: John, M., Walker. (Eds). The proteomics protocols handbook. Humana Press, p. 571-607. 
7. Harper, M.; Huang, H.C. (1986). Evaluation of the entomophagous fungus Verticillium lecanii (Moniliales: Moniliaceae) as a control agent for insects. Environ. Entomol. 15, 281-284.

8. Harper, A.M.; Huang, H.C. (1988). Insects killed by the fungus Verticillium lecanii, Canadex No. 621. Agriculture Canada, Ottawa, Ontario.

9. Hollis, T.; Monzingo, A.F.; Bortone, K.; Ernst, S.; Cox, R.; Robertus, J.D. (2000). The X-ray structure of a chitinase from the pathogenic fungus Coccidioides immitis. Protein. Sci. 9, 544-551.

10. Lu, Z.X.; Laroche, A.; Huang, H.C. (2005). Isolation and characterization of chitinases from Verticillium lecanii. Can. J. Microbiol. 51, 1045-1055.

11. Milner, R.J. (1997). Prospects for biopesticides for aphid control. Entomophaga. 42, 227-239.

12. Orikoshi, H.; Baba, N.; Nakayama, S.; Kashu, H.; Miyamoto, K.; Yasuda, M.; Inamori, Y.; Tsujibo, H. (2003). Molecular analysis of the gene encoding a novel cold-adapted chitinase $(\mathrm{ChiB})$ from a marine bacterium, Alteromonas sp. strain O-7. J. Bacteriol. 185, 1153-1160
13. Reader, U.; Broda, P. (1985). Rapid preparation of DNA from filamentous fungi. Lett. Appl. Microbiol. 1, 17-20.

14. Sambrook, J.; Fritsch, E.F.; Maniatis, T. (1989). Molecular cloning: a laboratory manual, 2nd edn. Cold Spring Harbor Laboratory Press, Cold Spring Harbor, New York.

15. Schwede, T.; Kopp, J.; Guex, N.; Peitsch, M.C. (2003). SWISSMODEL: an automated protein homology-modeling server. Nucleic Acids Res. 31, 3381-3385.

16. St. Leger, R.J.; Cooper, R.M.; Charnley, A.K. (1986). Cuticle degrading enzymes of entomopathogenic fungi: regulation of production of chitinolytic enzymes. J. Gen. Microbiol. 132, 1509-1517.

17. Terwisscha van Scheltinga, A.C.; Hennig, M.; Dijkstra, B.W. (1996). The $1.8 \AA$ resolution structure of hevamine a plant chitinase/ lysozyme and analysis of the conserved sequence and structure motifs of glycosyl hydrolase family 18. J. Mol. Biol. 262, 243-257.

18. Wattanalai, R.; Wiwat, C.; Boucias, D.G.; Tartar, A. (2004). Chitinase gene of the dimorphic mycopathogen, Nomuraea rileyi. J. Invertebr. Pathol. 85, 54-57. 